doi: $10.2306 /$ scienceasia1513-1874.2012.38.175

\title{
Microstructure and strength of blended FBC-PCC fly ash geopolymer containing gypsum as an additive
}

\author{
Kornkanok Boonserm $^{\mathrm{a}}$, Vanchai Sata ${ }^{\mathrm{a}}$, Kedsarin Pimraksa $^{\mathrm{b}}$, Prinya Chindaprasirt $^{\mathrm{a}, *}$ \\ a Sustainable Infrastructure Research and Development Centre, Department of Civil Engineering, \\ Faculty of Engineering, Khon Kaen University, Khon Kaen 40002 Thailand \\ b Department of Industrial Chemistry, Faculty of Science, Chiang Mai University, Chiang Mai 50200 Thailand
}

*Corresponding author, e-mail: prinya@kku.ac.th

Received 21 Dec 2011

Accepted 12 May 2012

\begin{abstract}
This study focused on the microstructure and strength of blended fluidized bed coal combustion fly ash (FBC-FA) and pulverized coal combustion fly ash (PCC-FA) geopolymers containing gypsum as an additive. The source materials consisted of 100\% FBC-FA and a blend of 75\% FBC-FA and 25\% PCC-FA. Gypsum was used as an additive at the dosage levels of 0,5 , and $10 \%$ wt of the source materials. $\mathrm{NaOH}$ and $\mathrm{Na}_{2} \mathrm{SiO}_{3}$ were used to activate aluminosilicate sources and temperature curing to accelerate the geopolymer reaction. The microstructures of the geopolymer pastes were examined using XRD, FTIR, MIP and SEM tests. The compressive strengths of the geopolymer mortars were also tested. Test results showed that the blending of FBC-FA and PCC-FA improved the geopolymerization and resulted in a dense matrix with reduced porosity and increased compressive strength as compared to those of the FBC-FA geopolymer. The improvement is due primarily to the high glassy phase content of PCC-FA. In addition, the use of 5\% gypsum as an additive further improved the geopolymerization. The sulphate ions enhanced the leaching of alumina from the source materials forming additional aluminosilicate and increased calcium in the system which resulted in the formation of additional CSH.
\end{abstract}

KEYWORDS: fluidized bed coal combustion, pulverized coal combustion, porosity, paste, mortar

\section{INTRODUCTION}

The pulverized coal combustion (PCC) process has been used to burn coal for almost a century. This technology requires less excess air whilst uses high firing temperature to improve thermal efficiency creating a spherical shape, highly amorphous phase contents, and reactive by-product materials such as fly ash. Fly ash from pulverized coal combustion (PCC-FA) is commonly used as a pozzolanic material for partial replacement of Portland cement in concrete work ${ }^{1,2}$. The recently developed fluidized bed coal combustion (FBC) technology for power plant supersedes PCC. The FBC process operates at lower burning temperatures and emits lower $\mathrm{CO}_{2}$, sulphur, and nitrogen oxide. The process can use burnable material such as grubby coal, municipal waste, and all types of biomass, including wood, rice husks, sugarcane bagasse, olive/palm oil residues, fruit residues, or even wet coffee as fuel materials. Even though the FBC method is a clean coal technology, it provides poorer grade of by-product materials.

In Thailand, the fluidized bed power plant normally uses two types of fuel, viz., coal and coal plus biomass. Biomass burning can use biological waste material derived from plants and animal wastes. The composition of biomass ashes is, therefore, quite variable. For example, wood contains low silica and high $\mathrm{CaO}$, while agricultural residues contains high silica and low calcium. The use of biomass to partially replace coal reduces the overall emission of greenhouse gas ${ }^{3}$. However, the FBC fly ash (FBC-FA) is irregular in shape, less reactive, and contains smaller proportion of glassy phase compare to the PCC-FA. It cannot replace cement replacement ${ }^{4}$, but it can be used as a source material for making geopolymer ${ }^{5}$. Geopolymer is an alkali-activated aluminosilicate material. The source material, therefore, contains high amorphous silica and alumina contents. It offers good strength, improved mechanical properties, and reduced $\mathrm{CO}_{2}$ emission ${ }^{6,7}$. Although FBC-FA can be used to produce geopolymer, the strength is low compared to that of the PCC-FA geopolymer ${ }^{8,9}$. The blending of FBC-FA with a high glassy phase material such as PCC-FA is recommended to improve the strength of FBC-FA geopolymer ${ }^{5}$.

The degree of geopolymerization can be increased by incorporating additives such as $\mathrm{CaCl}_{2}, \mathrm{CaSO}_{4}$, or $\mathrm{Na}_{2} \mathrm{SO}_{4}{ }^{10}$. Sulphate additives give slightly better performance than the chloride additive. $\mathrm{CaSO}_{4}$ or 
Table 1 Chemical compositions of FBC-C, FBC-Bi, PCC-FA, and G.

\begin{tabular}{lcccc}
\hline \multirow{2}{*}{$\begin{array}{l}\text { chemical } \\
\text { composition }\end{array}$} & \multicolumn{4}{c}{ Materials } \\
\cline { 2 - 5 } & FBC-C & FBC-Bi & PCC-FA & G \\
\hline $\mathrm{CaO}$ & 15.8 & 40.0 & 24.5 & 58.8 \\
$\mathrm{SiO}_{2}$ & 38.8 & 22.6 & 35.2 & - \\
$\mathrm{Al}_{2} \mathrm{O}_{3}$ & 17.6 & 10.0 & 16.5 & - \\
$\mathrm{Fe}_{2} \mathrm{O}_{3}$ & 11.9 & 7.6 & 13.6 & - \\
$\mathrm{SO}_{3}$ & 8.1 & 12.7 & 1.6 & 41.2 \\
$\mathrm{Na}_{2} \mathrm{O}$ & 0 & 0 & 2.7 & - \\
$\mathrm{MgO}$ & 4.0 & 3.4 & 3.2 & - \\
$\mathrm{K}_{2} \mathrm{O}$ & 2.3 & 1.5 & 1.9 & - \\
$\mathrm{P}_{2} \mathrm{O}_{5}$ & 0.5 & 1.1 & 0.2 & - \\
$\mathrm{TiO}_{2}$ & 0.7 & 0.7 & 0.3 & - \\
$\mathrm{LOI}$ & 0.5 & 0.5 & 0.4 & - \\
\hline
\end{tabular}

gypsum is a good choice as it available in the market at very reasonable cost.

This study, therefore, attempted to improve the compressive strength of geopolymer from FBC-FA. Gypsum was used to improve the FBC-FA and PCC-FA blend reaction. This knowledge would be instrumental to understand and use FBC-FA to produce geopolymeric material.

\section{MATERIALS AND METHODS}

\section{Materials}

The source materials for making geopolymer were fly ashes from FBC and PCC power plants. Two types of FBC-FA, viz., $100 \%$ coal burning (FBC-C) and $70 \%$ coal with $30 \%$ biomass burning (FBC-Bi) from central area and PCC-FA from Mae Moh Power Plant in northern Thailand were the source materials. Commercial graded gypsum (G) was selected as an additive to improve the geopolymer properties. The chemical compositions of FBC-C, FBC-Bi, PCC-FA, and $\mathrm{G}$ were determined by $\mathrm{XRF}$ analysis and shown in Table 1. The FBC-C, FBC-Bi, and PCC-FA consisted of $\mathrm{SiO}_{2}, \mathrm{Al}_{2} \mathrm{O}_{3}, \mathrm{Fe}_{2} \mathrm{O}_{3}$, and $\mathrm{CaO}$ as the main oxides. $\mathrm{SO}_{3}$ was also present in a substantial quantity in $\mathrm{FBC}$ ashes. The main components of $\mathrm{G}$ were $\mathrm{CaO}$ and $\mathrm{SO}_{3}$ oxides. The physical characteristics of materials are examined by analysing particle sizes, specific gravity, and percentages retained on No. 325 sieve and tabulated in Table 2. The median particle sizes of FBC-C, FBC-Bi, PCC-FA, and G were 22.6, 28.9, 63.5, and $6.4 \mu \mathrm{m}$, respectively, with the corresponding specific gravity of $2.69,2.78,2.52$, and 2.31 , respectively. Sodium silicate was a commercially available solution with $13.8 \% \mathrm{Na}_{2} \mathrm{O}, 32.2 \% \mathrm{SiO}_{2}$, and $54.0 \% \mathrm{H}_{2} \mathrm{O}$ by weight and sodium hydroxide $(\mathrm{NH})$ solution at $10 \mathrm{M}$
Table 2 Physical characteristics of $\mathrm{FBC}-\mathrm{C}, \mathrm{FBC}-\mathrm{Bi}$, PCC-FA, and G.

\begin{tabular}{lccc}
\hline Materials & $\begin{array}{c}\text { Median particles } \\
\text { size }(\mu \mathrm{m})\end{array}$ & $\begin{array}{c}\text { Specific } \\
\text { gravity }\end{array}$ & $\begin{array}{c}\text { Retained on } \\
\text { sieve \#325 }(\%)\end{array}$ \\
\hline FBC-C & 22.6 & 2.69 & 15.1 \\
FBC-Bi & 28.9 & 2.78 & 21.7 \\
PCC-FA & 63.5 & 2.52 & 50.0 \\
G & 6.4 & 2.31 & 3.0 \\
\hline
\end{tabular}

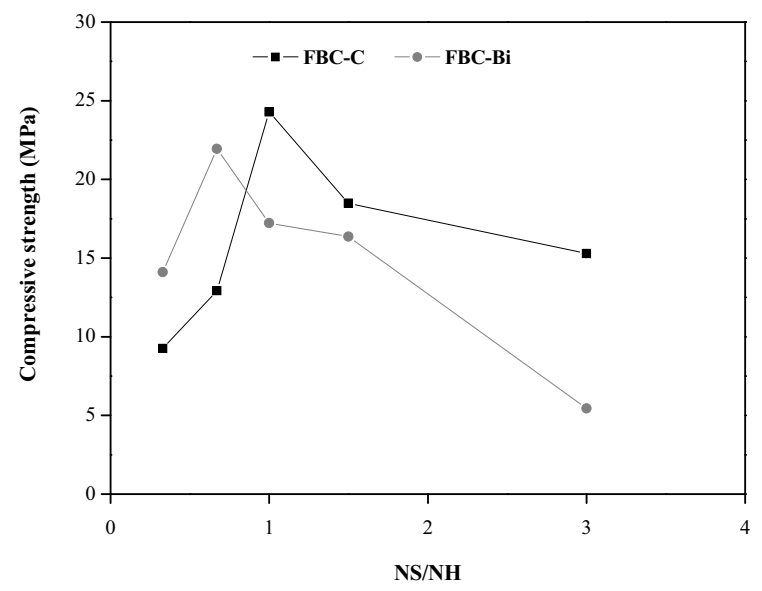

Fig. 1 Compressive strength of FBC-C and FBC-Bi geopolymers based on NS/NH ratios.

concentration was prepared one day before mixing to ensure equilibrium. The $\mathrm{NH}$ and $\mathrm{NS}\left(\mathrm{Na}_{2} \mathrm{SiO}_{3}\right)$ were used as alkali activators. Local river sand with specific gravity of 2.62 and fineness modulus of 2.85 was used to make geopolymer mortar.

\section{Details of mixing and testing}

The source materials were the FBC-FA and the blend of $75 \%$ wt FBC-FA and 25\% wt PCC-FA. Three levels of gypsum additive of 0,5 , and $10 \%$ by weight of solid binder content were used. The liquid/ash (L/A) ratio of 1.0 and sand/ash ratio of 2.75 were used for both FBC-C and FBC-Bi mixes. The NS/NH ratios of 1.0 and 0.67 for FBC-C and FBC-Bi geopolymers were selected from the optimum compressive strengths from the trial mixes (Fig. 1). The details proportion details are tabulated in Table $3 . \mathrm{SiO}_{2} / \mathrm{Al}_{2} \mathrm{O}_{3}$ and $\mathrm{Na}_{2} \mathrm{O} / \mathrm{Al}_{2} \mathrm{O}_{3}$ ratios were calculated from the source materials and alkaline solution in the reaction.

The FBC-FA and PCC-FA were blended thoroughly to obtain a uniform blended source material. Gypsum was added to the source material and mixed in a container. $\mathrm{NH}$ solution was added and mixed for $5 \mathrm{~min}$. After that, NS solution was added and 
Table 3 Mix proportions and oxide molar ratio of blended FBC-FA and PCC-FA containing $\mathrm{G}$ as an additive.

\begin{tabular}{lcrcc}
\hline Mixes & $\begin{array}{c}\text { FBC-FA: } \\
\text { PCC-FA }\end{array}$ & $\mathrm{G}(\%)$ & $\begin{array}{c}\mathrm{SiO}_{2} / \\
\mathrm{Al}_{2} \mathrm{O}_{3}\end{array}$ & $\begin{array}{c}\mathrm{Na}_{2} \mathrm{O} / \\
\mathrm{Al}_{2} \mathrm{O}_{3}\end{array}$ \\
\hline FBC-C100-G0 & $100: 0$ & 0 & 5.29 & 1.74 \\
FBC-C100-G5 & & 5 & 5.38 & 1.83 \\
FBC-C100-G10 & & 10 & 5.47 & 1.93 \\
FBC-C75-G0 & $75: 25$ & 0 & 5.29 & 1.83 \\
FBC-C75-G5 & & 5 & 5.37 & 1.93 \\
FBC-C75-G10 & & 10 & 5.46 & 2.03 \\
FBC-Bi100-G0 & $100: 0$ & 0 & 6.02 & 3.22 \\
FBC-Bi100-G5 & & 5 & 6.14 & 3.39 \\
FBC-Bi100-G10 & & 10 & 6.26 & 3.58 \\
FBC-Bi75-G0 & $75: 25$ & 0 & 5.64 & 2.87 \\
FBC-Bi75-G5 & & 5 & 5.74 & 3.01 \\
FBC-Bi75-G10 & & 10 & 5.85 & 3.18 \\
\hline
\end{tabular}

† Control mix.

mixed for another $5 \mathrm{~min}$. After mixing, the fresh paste was casted in $5 \times 5 \times 5 \mathrm{~cm}$ cubic plastic moulds in accordance with ASTM C109 and compacted in a vibrating table for $10 \mathrm{~s}$. The mould was then wrapped with polyvinyl sheet to prevent a loss of moisture. Samples were cured in an electric oven at $40^{\circ} \mathrm{C}$ for $48 \mathrm{~h}$ and then kept at $25^{\circ} \mathrm{C}$ and $50 \%$ R.H. room until testing. The paste samples were used for the XRD, FTIR, MIP, and SEM analyses. For the geopolymer mortar, sand was added at the final stage and mixed again for $5 \mathrm{~min}$. The curing regime was the same as the paste samples. The compressive strength of mortar was tested at the age of 7 days in accordance with ASTM C109.

\section{RESULTS AND DISCUSSION}

\section{Compressive strength}

The results of compressive strength of mortars are shown in Fig. 2. The strength of FBC-C mortar was slightly higher than that of FBC-Bi mortar. The compressive strengths of FBC-C100-G0 and FBC-Bi100G0 control mortar mixes were 21.5 and $19.6 \mathrm{MPa}$, respectively. The FBC-C contained a higher percentage of silica and alumina than those of FBC-Bi (Table 1). Although the reactivity of both FBC-C and FBC-Bi were low, the high silica and alumina of FBC-C was responsible for its slightly better performance than that of FBC-Bi. Blends of FBC-FA and PCC-FA significantly improved the strengths of mortars compared to the control mortars with no PCC-FA. The compressive strengths of blended FBC-C and PCC-FA, and FBC-Bi and PCC-FA mortars increased to 25.8

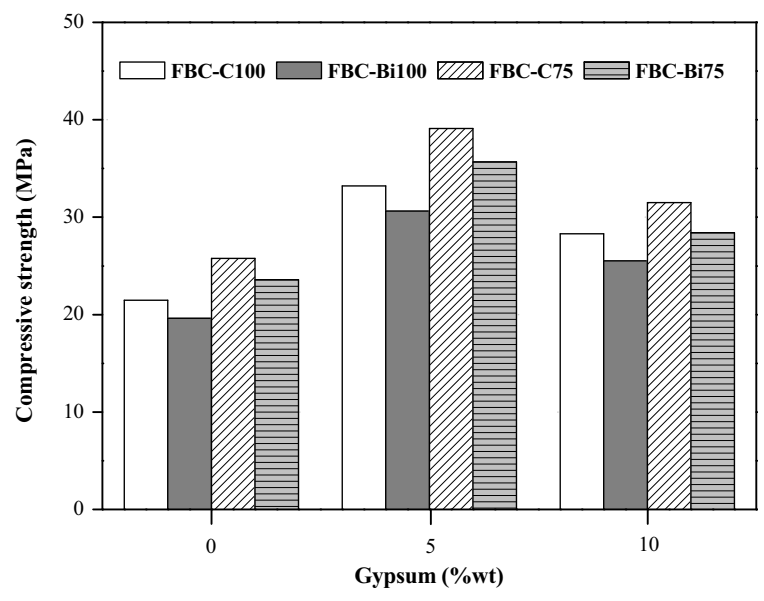

Fig. 2 Compressive strength of FBC-C and FBC-Bi based geopolymer mortars.

and 23.4 MPa, respectively. In addition, calcium silicate hydrate (CSH) gel from the reaction between $\mathrm{Ca}^{2+}$ from ashes and silicate group could increase the strength of the matrix ${ }^{10}$. The increase in strength in this case was due to the increased reactive amorphous phase of the mixture resulted from the blending of FBC-FA with PCC-FA ${ }^{11}$.

The incorporation of $5 \% \mathrm{G}$ as an additive further improved the compressive strengths of the mortars (Fig. 2). Addition 5\% G increases the compressive strengths of FBC-C100-G5 and FBC-Bi100-G5 mortars to 33.2 and $30.6 \mathrm{MPa}$, respectively. The additions of $10 \% \mathrm{G}$ also produced geopolymer mortars with high strength but were slightly lower than those with the addition of $5 \% \mathrm{G}$. The high amount of $\mathrm{G}$ hindered the geopolymer reaction and slightly decreased the strength of the geopolymer mortars ${ }^{10}$. The compressive strengths of FBC-C100-G10 and FBC-Bi100G10 were 28.3 and $25.5 \mathrm{MPa}$, respectively.

For the blended fly ash mortars, the addition of $\mathrm{G}$ also showed the same trend of results as that of the FBC-FA mortars. The optimum increase in strength was obtained with the addition of $5 \%$ G. For the blended FBC-C and PCC-FA, the maximum compressive strength was $39.1 \mathrm{MPa}$ with the addition of $5 \% \mathrm{G}$. For the blended FBC-Bi and PCC-FA, the maximum compressive strength was $35.7 \mathrm{MPa}$ also with the addition of $5 \% \mathrm{G}$. The increase in the strength is due to the $\mathrm{Ca}^{2+}$ ions from $\mathrm{G}$ entering the $\mathrm{Si}-\mathrm{O}-\mathrm{Al}-\mathrm{O}$ framework and balancing the charge on $\mathrm{Al}$ ions ${ }^{12}$. This played an important role to form the CSH and the stronger aluminosilicate structure and contributed to strength improvement. Furthermore, the $\mathrm{SO}_{4}^{2-}$ ions from $\mathrm{G}$ attacked the $\mathrm{Al}$ ions from ashes ${ }^{13,14}$ and form 


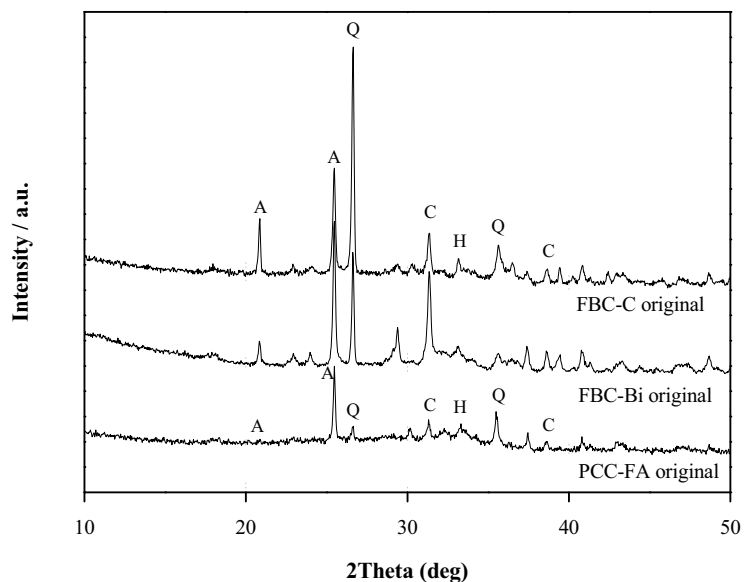

Fig. 3 XRD patterns of FBC-C, FBC-Bi, and PCC-FA originals $(\mathrm{A}=$ anhydrite, $\mathrm{C}=$ calcium oxide, $\mathrm{H}=$ haematite, $\mathrm{Q}=$ quartz).

aluminosilicate hydrate and geopolymer framework which help the strength development. However, the increase of $\mathrm{G}$ to $10 \% \mathrm{wt}$ gave lower compressive strength than that of $\mathrm{G} 5 \% \mathrm{wt}$. There was an optimum $\mathrm{SO}_{4}^{2-}$ ions content which produced the highest compressive strength, with higher $\mathrm{SO}_{4}^{2-}$ ions content hindering the process of geopolymerization.

\section{$\mathrm{X}$-ray diffraction}

The X-ray diffraction (XRD) patterns of the source materials are shown in Fig. 3. The crystalline phases of quartz (Q: $\left.\mathrm{SiO}_{2}\right)$, anhydrite $\left(\mathrm{A}: \mathrm{CaSO}_{4}\right)$, calcium oxide $(\mathrm{C}: \mathrm{CaO})$, and haematite $\left(\mathrm{H}: \mathrm{Fe}_{2} \mathrm{O}_{3}\right)$ were found in all FBC-Bi, FBC-C, and PCC-FA. The amount of $\mathrm{CaO}$ in $\mathrm{FBC}-\mathrm{Bi}$ and quartz content were higher than those of FBC-C and PCC-FA. The FBC-C and FBC-Bi clearly showed lower content of amorphous phase than that of PCC-FA evident by a broad hump around $16-38^{\circ}(2 \theta)$. This was due to the low combustion temperature of coal in the FBC system.

The XRD patterns of geopolymer paste are shown in Fig. 4. The XRD patterns of the source materials and those of geopolymer pastes differed in the amount of crystalline and amorphous phases. For the FBC-C and $\mathrm{FBC}-\mathrm{Bi}$ pastes, the intensities of $\mathrm{SiO}_{2}(\mathrm{Q})$ and $\mathrm{CaO}(\mathrm{C})$ peak decreased, while $\mathrm{CSH}(\mathrm{X})$, aluminosilicate (U), Magnesioferrite (F) and amorphous phase increased compared to those of the source materials. The broad humps of aluminosilicate gel around $30^{\circ}$ $(2 \theta)$ of the FBC-C pastes (Fig. 4a) were more pronounce than those of the FBC-Bi pastes (Fig. $4 b$ ). This suggested that the geopolymerizations of the FBC-C pastes were more advanced and agreed with
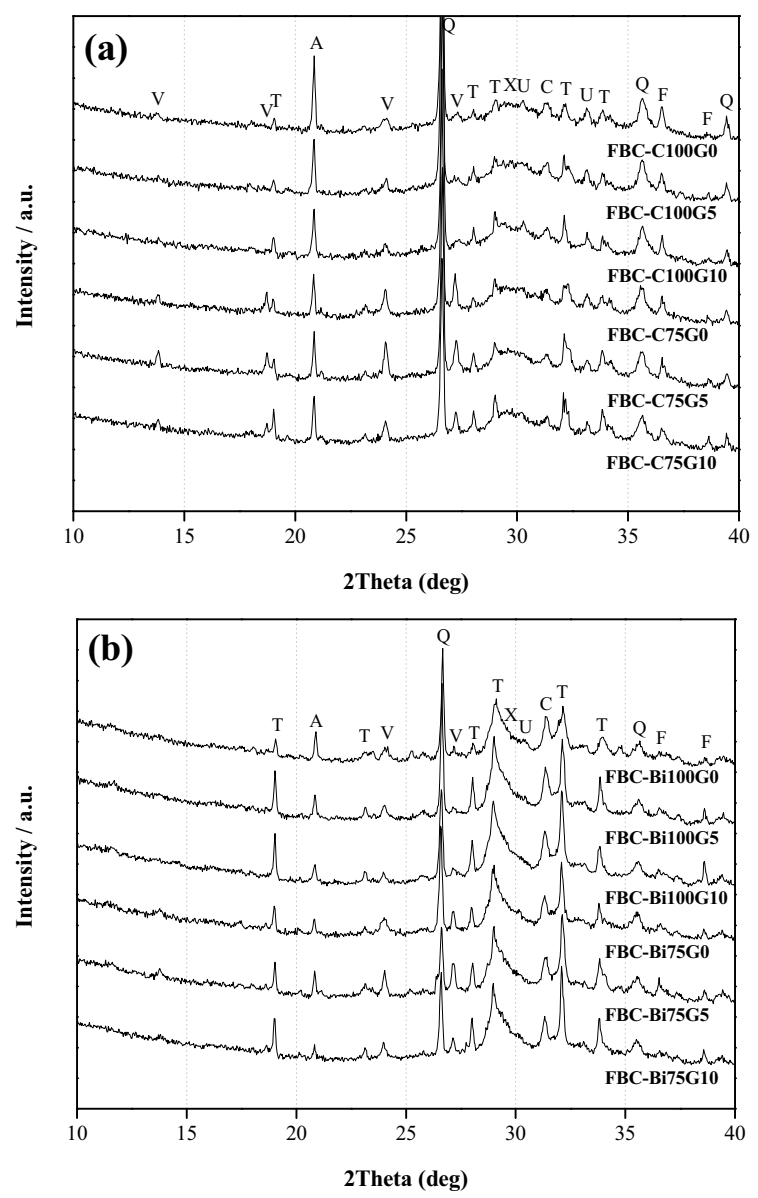

Fig. 4 XRD patterns of geopolymer pastes, (a) FBC-C and (b) FBC-Bi ( $\mathrm{A}=$ anhydrite, $\mathrm{C}=$ calcium oxide, $\mathrm{F}=$ magnesioferrite, $\mathrm{Q}=$ quartz, $\mathrm{T}=$ thenardite, $\mathrm{U}=$ aluminosilicate, $\mathrm{V}=$ vishnevite, $\mathrm{X}=$ calcium silicate hydrate).

the higher compressive strength of the FBC-C pastes compared to those of the FBC-Bi pastes. Moreover, two new compounds, viz., zeolite named vishnevite (V: $\mathrm{Na}_{8} \mathrm{Al}_{6} \mathrm{Si}_{6} \mathrm{O}_{24}\left(\mathrm{SO}_{4}\right) \cdot 2 \mathrm{H}_{2} \mathrm{O}$ ) and thenardite ( $\mathrm{T}$ : $\mathrm{NaSO}_{4}$ ) were detected.

The blending of PCC-FA with FBC-C and FBC-Bi resulted in a reduction in the anhydrite content and an increase in the $\mathrm{CSH}$, aluminosilicate, and vishnevite phases. The existence of some crystalline phase improved the strength of geopolymer paste ${ }^{15}$. Adding 5\% wt G in FBC-C and FBC-Bi showed similar trend to those of the blending with PCC-FA with additional increases in, aluminosilicate, $\mathrm{CSH}$, vishnevite, and thenardite phases. The addition of $10 \% \mathrm{wt}$ $G$ resulted in an increase in thenardite phase but decrease in vishnevite phase compared to the addition of 
$5 \%$ wt $\mathrm{G}$. The reduction in the strength of geopolymer with the high amount of $\mathrm{G}$ was due to the reduction of vishnevite phase and the increase in the thenardite phase. It was suggested that the high percentage of $\mathrm{Na}_{2} \mathrm{SO}_{4}(\mathrm{~T})$ existed as an impurity in the matrix ${ }^{16}$. Comparing the XRDs of Fig. $4 \mathrm{a}$ and Fig. $4 \mathrm{~b}$ revealed that the phases of aluminosilicate and vishnevite of the mixes in FBC-C series were more pronounced than those of the mixes in FBC-Bi series. This confirmed that the higher strengths of FBC-C series compared to those of FBC-Bi series were probably due to the presence of the aluminosilicate and zeolite phase of vishnevite ${ }^{17}$.

\section{IR spectra}

The Fourier Transform Infrared Spectroscopy (FTIR) was used to study the reaction of original materials and geopolymer pastes. The chemical bonding of IR spectra and results are shown in Fig. 5. The vibration of $\mathrm{CO}_{3}^{2-}$ at about $1500 \mathrm{~cm}^{-1}$ indicated the $\mathrm{Na}_{2} \mathrm{CO}_{3}$ from carbonation process ${ }^{18}$. The vibrations at $3700-3200 \mathrm{~cm}^{-1}$ of $\mathrm{O}-\mathrm{H}$ stretching and 1700 $1600 \mathrm{~cm}^{-1}$ of $\mathrm{H}-\mathrm{O}-\mathrm{H}$ bending showed the weak bond of water molecules which were easily adsorbed on the surface or trapped in large cavities between the rings of geopolymer materials. The $\mathrm{Si}-\mathrm{O}-\mathrm{Si}$ and $\mathrm{Al}-\mathrm{O}-\mathrm{Si}$ stretching of geopolymer pastes at the wavenumber of $1200-950 \mathrm{~cm}^{-1}$ were more prominent than in original materials. The blending with PCC-FA also showed all the common features of carbonation, $\mathrm{O}-\mathrm{H}$ stretching and $\mathrm{H}-\mathrm{O}-\mathrm{H}$ bending, and $\mathrm{Si}-\mathrm{O}-\mathrm{Si}$ and $\mathrm{Al}-\mathrm{O}-\mathrm{Si}$ stretching. The noticeable difference was the larger $\mathrm{Si}-\mathrm{O}-\mathrm{Si}$ and $\mathrm{Al}-\mathrm{O}-\mathrm{Si}$ stretching band of the paste made from blending of FBC-FA with PCC-FA compared to that of the FBC-FA pastes. The increase in the $\mathrm{Si}-\mathrm{O}-\mathrm{Si}$ and $\mathrm{Al}-\mathrm{O}-\mathrm{Si}$ stretching band indicated the increase in the geopolymerization ${ }^{5}$.

The addition of $5 \% \mathrm{wt} \mathrm{G}$ resulted in the increase of the intensity of $\mathrm{Al}-\mathrm{O}-\mathrm{Si}$ and $\mathrm{S}=\mathrm{O}$ stretching at the wavenumber around $950-1200 \mathrm{~cm}^{-1}$ and vibration of $\mathrm{Na}_{2} \mathrm{SO}_{4}$ at the wavenumber of $636 \mathrm{~cm}^{-1}$. The increase of $\mathrm{G}$ content to $10 \%$ wt resulted in the high calcium and $\mathrm{SO}_{4}^{2-}$ content. This provided the high band of $\mathrm{Na}_{2} \mathrm{SO}_{4}$ at the wavenumber of $636 \mathrm{~cm}^{-1}$. The strength started to decline as $\mathrm{Na}_{2} \mathrm{SO}_{4}$ did not contribute to the strength of geopolymer.

\section{Porosity}

The total porosity of geopolymer pastes were measured by mercury intrusion porosimetry analysis (Fig. 6). For the control mixes, FBC-C100-G0 and FBC-Bi100-G0 contained the total porosity of $20.4 \%$ and $21.7 \%$, respectively. The use of the blends of
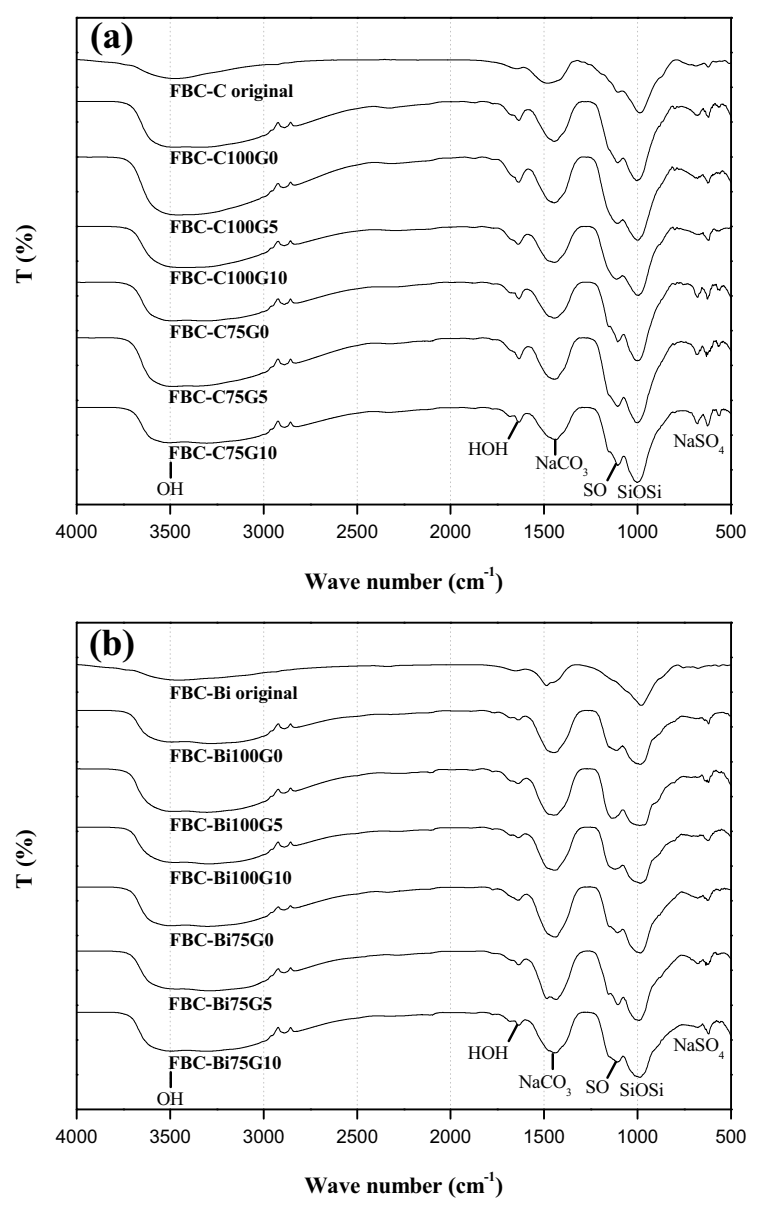

Fig. 5 FTIR spectra of original materials and geopolymer pastes, (a) FBC-C and (b) FBC-Bi.

FBC-FA and PCC-FA significantly reduced the total porosity of the pastes compared to the control mixes. The total porosity of blended FBC-C and PCC-FA; and FBC-Bi and PCC-FA decreased to 14.3 and $16.2 \%$, respectively. The spherical shape and smooth surface of PCC-FA particle offered better distribution than that of FBC fly ash which comprised with irregular shape and high porosity particle. Additionally, PCC-FA was more effective in adjusting pores and decreasing the porosity of paste ${ }^{19}$.

The addition of $\mathrm{G}$ as an additive could reduce the total porosity. For the incorporation of $5 \% \mathrm{G}$, the total porosity of FBC-C100-G5 and FBC-Bi100-G5 pastes were decreased to 16.5 and $17.1 \%$, respectively. Although the additions of $10 \% \mathrm{G}$ reduced the total porosity of geopolymer pastes compared with that of the control $0 \% \mathrm{G}$, they were higher than those with the addition of $5 \% \mathrm{G}$. This confirmed that the addition of $5 \% \mathrm{G}$ produced a dense matrix with low porosity and 


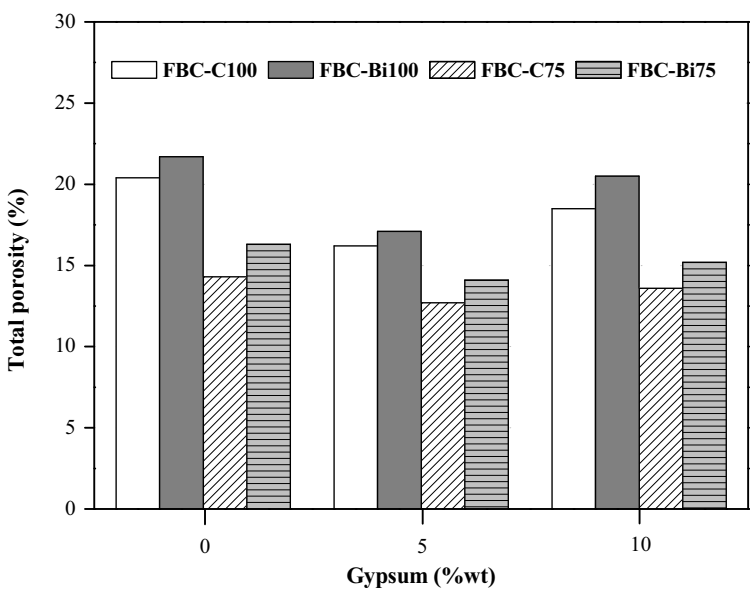

Fig. 6 Total porosity of geopolymer pastes from FBC-C and FBC-Bi.

the increase in $\mathrm{G}$ content to $10 \%$ started to hinder the reaction. The total porosity of FBC-C100-G10 and FBC-Bi100-G10 were 18.5 and $20.5 \%$, respectively.

For the blended fly ash pastes, the addition of $\mathrm{G}$ also showed a similar trend of results as that of the FBC-FA pastes. The optimum decreased in total porosity occurred with the addition of $5 \% \mathrm{G}$. For the blended FBC-C and PCC-FA, the total porosity was $12.7 \%$ with the addition of $5 \% \mathrm{G}$. For the blended FBC-Bi and PCC-FA, the minimum total porosity was $14.1 \%$ also with the addition of $5 \% \mathrm{G}$. The $\mathrm{Ca}^{2+}$ ions from $\mathrm{G}$ were interconnected with $\mathrm{Si}-\mathrm{O}-\mathrm{Al}-\mathrm{O}$ chains thus provided the stronger structure and also decreased of the total porosity ${ }^{20}$. The incorporation of $10 \% \mathrm{G}$ also produced geopolymer pastes with low total porosity but was slightly higher than those with the addition of $5 \% \mathrm{G}$. For the blended FBC-C and PCC-FA, the total porosity was $13.6 \%$ with the addition of $10 \% \mathrm{G}$. For the blended FBC-Bi and PCC-FA, the minimum total porosity was $15.2 \%$ with the addition of $5 \% \mathrm{G}$.

\section{Scanning electron microscopy}

The scanning electron microscopy (SEM) of geopolymer pastes are shown in Fig. 7. The matrix of FBC-C75 with 5\% $\mathrm{G}$ was denser than that of FBC-C75 with 0 and $10 \% \mathrm{G}$ as shown in Fig. 7a. This reflected an enhancement of geopolymerization by the addition of $5 \% \mathrm{G}$. With regard to the effect of PCC-FA, the results shown in Fig. 7b indicate that the replacement of $25 \%$ PCC-FA resulted in homogeneous and dense matrices in comparison to those without PCC-FA (FBC-Bi100) for both 0 and $5 \% \mathrm{G}$ series. This confirmed that the PCC-FA was more
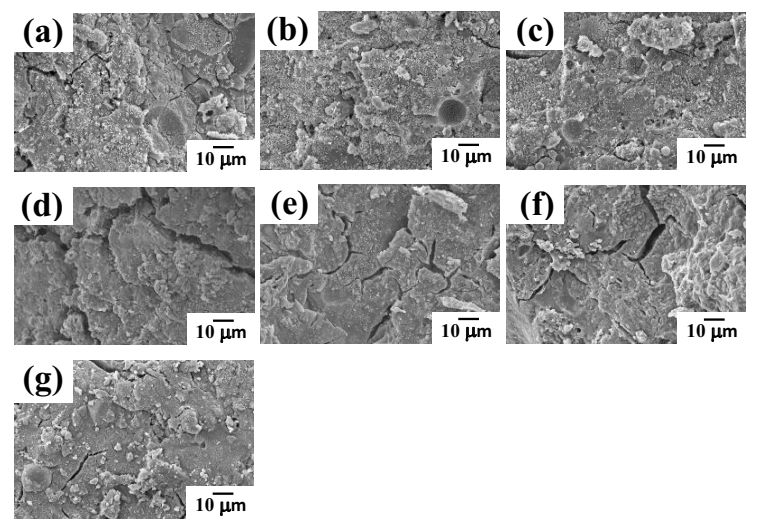

Fig. 7 SEM photography of geopolymer pastes, (a) FBC-C75G0, (b) FBC-C75G5, (c) FBC-C75G10, (d) FBC-Bi100G0, (e) FBC-Bi100G5, (f) FBC-Bi75G0, and (g) FBC-Bi75G5.

reactive and contained a higher amount of amorphous phase than the FBC-FA ${ }^{11}$.

\section{CONCLUSIONS}

The FBC-C and FBC-Bi could be used as source materials for the production of geopolymer. The blending with 25\% wt PCC-FA improved the geopolymerization and resulted in geopolymer pastes with increased compressive strengths and reduced porosity. The improvement was due to the blending with the more reactive PCC-FA. The addition of G further improved the geopolymerization of the paste and resulted in additional increase in strength and reduction in porosity. The incorporation of $5 \%$ wt $\mathrm{G}$ was optimum. The increase in $\mathrm{Ca}^{2+}$ ions from $\mathrm{G}$ formed additional $\mathrm{CSH}$ and improved the strength and reduced the total porosity of geopolymer.

Acknowledgements: This work was financial supported by the Thailand Research Fund (TRF) under the TRF Senior Research Scholar, Grant No. RTA5480004 and the Royal Golden Jubilee Ph.D. program, Grant No. PHD/0210/2551 in collaboration with the SCG Paper Public Company Limited, Thailand.

\section{REFERENCES}

1. Malhotra VM (2002) Introduction: sustainable development and concrete technology. ACI Concr Int 24, 22.

2. Sinsiri T, Teeramit P, Jaturapitakkul C, Kiattikomol K (2006) Effect of Finenesses of Fly Ash on Expansion of Mortars in Magnesium Sulfate. Sci Asia 32, 63-9.

3. Prasertsan S, Sajjakulnukit B (2006) Biomass and biogas energy in Thailand: potential, opportunity and barriers. Renew Energ 31, 599-610. 
4. Jaturapitakkul C, Cheerarot R (2003) Development of bottom ash as pozzolanic material. J Mater Civ Eng 15, 48-53.

5. Chindaprasirt P, Rattanasak U, Jaturapitakkul C (2011) Utilization of fly ash blends from pulverized coal and fluidized bed combustions in geopolymeric materials. Cement Concr Compos 33, 55-60.

6. Davidovits J (1994) Properties of geopolymer cements. In: Krivenko PV (ed) Proceedings of the 1st International Conference on Alkaline Cements and Concretes, Ukraine, pp 131-49.

7. Duxson P, Provis JL, Grant C, Van Deventer JSJ (2007) The role of inorganic polymer technology in the development of 'green concrete'. Cement Concr Res 37, 1590-7.

8. Chindaprasirt P, Chareerat T, Sirivivatnanon V (2007) Workability and strength of coarse high calcium fly ash geopolymer. Cement Concr Compos 29, 224-9.

9. Chindaprasirt P, Jaturapitakkul C, Chalee W, Rattanasak U (2009) Comparative study on the characteristics of fly ash and bottom ash geopolymers. Waste Manag 29, 539-43.

10. Rattanasak U, Pankhet K, Chindaprasirt P (2011) Effect of chemical admixtures on properties of high-calcium fly ash geopolymer. Int J Miner Metall Mater 18, 364-9.

11. Chindaprasirt P, Rattanasak U (2010) Utilization of blended fluidized bed combustion (FBC) ash and pulverized coal combustion (PCC) fly ash in geopolymer. Waste Manag 30, 667-72.

12. Fernández-Jiménez A, Palomo A, Sobrados I, Sanz J (2006) The role played by the reactive alumina content in the alkaline activation of fly ashes. Micropor Mesopor Mat 91, 111-9.

13. Ma W, Liu C, Brown PW, Komarneni S (1995) Pore structures of fly ashes activated by $\mathrm{Ca}(\mathrm{OH})_{2}$ and $\mathrm{CaSO}_{4} \cdot 2 \mathrm{H}_{2} \mathrm{O}$. Cement Concr Res 25, 417-25.

14. Pimraksa K, Chindaprasirt $P$ (2009) Lightweight bricks made of diatomaceous earth, lime and gypsum. Ceram Int 35, 471-8.

15. Rattanasak U, Chindaprasirt $P$ (2009) Influence of $\mathrm{NaOH}$ solution on the synthesis of fly ash geopolymer. Miner Eng 22, 1073-8.

16. Luke K (2007) The effect of natural zeolites on the composition of cement pore fluids at early ages. In: Proceedings of 12th International Congress on the Chemistry of Cement, Halliburton, USA.

17. Höller H, Wrisching U (1985) Zeolites formation from fly ash. Fortschr Mineral 63, 21-43.

18. Barbosa VFF, MacKenzie KJD, Thaumaturgo C (2000) Synthesis and characterization of materials based on inorganic polymers of alumina and silica: sodium polysialate polymer. Int J Inorg Mater 2, 309-17.

19. Sinsiri T, Chindaprasirt P, Jaturapitakkul C (2010) Influence of fly ash fineness and shape on the porosity and permeability of blended cement pastes. Int J Miner Metall Mater 17, 683-90.
20. Škvára F, Kopecký L, Šmilauer V, Bittnar Z (2009) Material and structural characterization of alkali activated low-calcium brown coal fly ash. J Hazard Mater 168, 711-20. 